\title{
Avascular necrosis of bone complicating corticosteroid replacement therapy
}

\author{
P. L. WILLIAMS AND MARY CORBETT \\ From the Department of Rheumatology, Middlesex Hospital, London WIP 9PG
}

SUMMARY Two patients who developed widespread severe avascular necrosis of bone while on steroid replacement therapy are described. One, a diabetic, underwent yttrium-90 pituitary ablation for retinopathy and developed avascular necrosis within 18 months of starting prednisolone. The other, who had Addison's disease, developed avascular necrosis within 14 months of starting cortisol replacement therapy. Both cases came to bilateral total hip replacement.

The association between corticosteroid treatment and avascular necrosis of bone (ANB) is well established. However, ANB as a complication of replacement steroid therapy is not widely recognised, though there are sporadic cases in the literature. We report 2 cases and briefly discuss the implications.

\section{Case reports}

\section{CASE 1}

A 33-year-old diabetic male underwent pituitary ablation with an implant of yttrium-90, dose 300000 rads, on 21 September 1973, because of proliferative retinopathy of the right eye. Diabetic since 14 , he had been well controlled on twice-daily soluble insulin, and had no evidence of peripheral neuropathy or renal impairment. At the age of 22 his left eye was enucleated following a gunshot injury.

Following the implant he was given prednisolone $20 \mathrm{mg}$ tds for 2 days, reducing to $2.5 \mathrm{mg}$ tds within one week, and $2.5 \mathrm{mg}$ bd at discharge. In November 1973 he developed pneumococcal meningitis, treated successfully with parenteral sulphadiazine, benzyl penicillin, and chloramphenicol. Steroid dosage was temporarily increased but reduced to $2.5 \mathrm{mg}$ tds 3 weeks after discharge.

Hormonal replacement was also given as testosterone $250 \mathrm{mg}$ intramuscularly monthly from December 1973 and thyroxine $200 \mu \mathrm{g}$ daily from June 1974.

His diabetes remained under good control on soluble insulin 4 units bd and isophane 4 units mane.

Accepted for publication 5 May 1982.

Correspondence to Dr P. L. Williams, Royal National Orthopaedic Hospital, 234 Great Portland Street, London W1N 6AD.
Prednisolone dosage was reduced to $2.5 \mathrm{mg}$ bd in April 1974, and $2.5 \mathrm{mg}$ od in October 1975.

In November 1975 he was admitted to hospital for assessment, with a history of 8 months pain and stiffness in both hips, beginning in the right, followed by stiffness in both shoulders and knees. $X$-rays showed advanced changes of avascular necrosis in the right shoulder with separation of a large fragment of the humeral head, and in the right hip with separation of a posterior superior fragment of the femoral head. There were less marked changes of avascular necrosis in the left shoulder and hip.

Because of multiple joint involvement non-weight bearing was impossible, and his hip symptoms progressed. A right total hip replacement was performed in March 1976 and a left in May 1978. Prednisolone was continued at $2-3 \mathrm{mg} /$ day in divided doses and his shoulder symptoms controlled with nonsteroidal anti-inflammatory drugs.

\section{INVESTIGATIONS}

Chest $x$-ray, haemoglobin, erythrocyte sedimentation rate (ESR), urea and electrolytes, uric acid, liver function tests, calcium, phosphate, immunoglobulins, and autoantibody profile were normal. The latex test for rheumatoid factor, antinuclear factor test, and a search for lupus erythematosus (LE) cells were negative. An insulin tolerance test (ITT) was performed to assess pituitary function 3 months after the implant, when cortisol was measured 30,60 , and 90 minutes after $0.3 \mathrm{unit} / \mathrm{kg}$ of intravenous soluble insulin. The basal cortisol level was $4 \cdot 6 \mu \mathrm{g} / \mathrm{dl}(127 \mathrm{nmol} / \mathrm{l})$ (normal 4-21 $\mu \mathrm{g} / \mathrm{dl}(110-580 \mathrm{nmol} / \mathrm{l})$ ) and all subsequent values less than $4.0 \mu \mathrm{g} / \mathrm{dl}(110 \mathrm{nmol} / \mathrm{l})$. The patient was taken off replacement steroid for the test, and although he showed no signs of steroid with- 
drawal he was clearly deficient biochemically and therefore put back on $7.5 \mathrm{mg}$ prednisolone/day.

Severe cortisol deficiency was again confirmed on 10 November 1975 , when an ITT was repeated after $0 \cdot 15 \mathrm{unit} / \mathrm{kg}$ of intravenous soluble insulin. After a basal cortisol level of $1.0 \mu \mathrm{g} / \mathrm{dl}(27.6 \mathrm{nmol} / \mathrm{l})$, subsequent levels up to 90 minutes did not rise above 1.0 $\mu \mathrm{g} / \mathrm{dl}$. Fasting triglycerides at this time were $90 \mathrm{mg} / \mathrm{dl}$ $(1.02 \mathrm{mmol} / \mathrm{l})$ (normal $60-140 \mathrm{mg} / \mathrm{dl}(0.7-1.6$ $\mathrm{mmol} / \mathrm{l})$ ) and cholesterol $270 \mathrm{mg} / 100 \mathrm{ml}(6.99$ $\mathrm{mmol} / \mathrm{l}$ ) (normal 140-240 $\mathrm{mg} / \mathrm{dl}(3 \cdot 6-6 \cdot 2 \mathrm{mmol} / \mathrm{l})$ ). Three further estimations of fasting cholesterol were normal.

\section{CASE 2}

A 33-year-old woman with a history of lethargy and depression for several months was admitted for investigation on 13 August 1969 because of symptoms of postural hypotension. On examination she had extensive vitiligo. Blood pressure was $80 / 55$ $\mathrm{mmHg}$. Haemoglobin, white blood cell count, and ESR were normal, sodium $102 \mathrm{mmol} / \mathrm{l}$, potassium $4.9 \mathrm{mmol} / \mathrm{l}$, chloride $74 \mathrm{mmol} / \mathrm{l}$, urea $60 \mathrm{mg} / \mathrm{dl}(10$ $\mathrm{mmol} / \mathrm{l})$, glucose $90 \mathrm{mg} / \mathrm{dl}(5 \mathrm{mmol} / \mathrm{l})$, calcium and phosphate normal. A morning cortisol level was $4 \cdot 5$ $\mu \mathrm{g} / \mathrm{dl}(124 \mathrm{nmol} / \mathrm{l})$. A provisional diagnosis of Addison's disease was made, and her physical state improved after treatment with hydrocortisone $100 \mathrm{mg}$ 6-hourly and normal saline intravenously, followed by oral cortisone $12 \cdot 5 \mathrm{mg}$ tds and fludrocortisone $0 \cdot 1$ $\mathrm{mg}$ on alternative days. At discharge the urea and electrolytes had returned to normal, and a morning plasma cortisol was $28 \mu \mathrm{g} / \mathrm{dl}(773 \mathrm{nmol} / \mathrm{l})$.

However, she continued to be lethargic and withdrawn and was admitted to the Middlesex Hospital on 30 January 1970. Examination, including blood pressure, gave normal results apart from vitiligo. Haemoglobin, white blood cell count, ESR, urea and electrolytes, liver function tests, protein bound

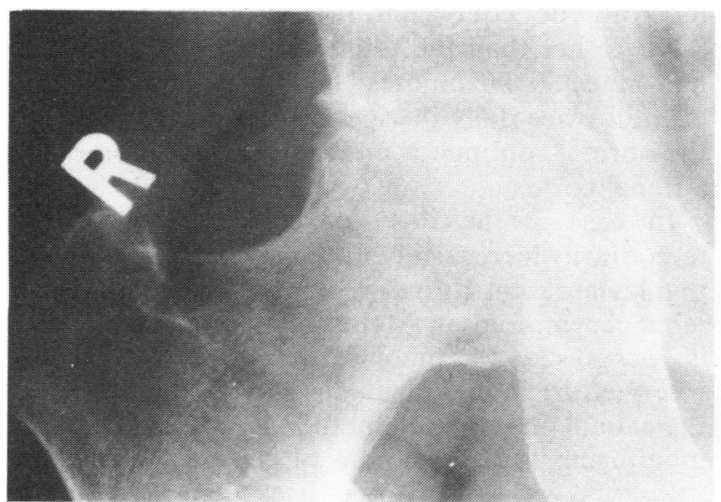

iodine, and $x$-rays of chest and skull were normal. Plasma cortisols were $6 \mu \mathrm{g} / \mathrm{dl}(166 \mathrm{nmol} / \mathrm{l})$ at $8 \mathrm{am}$ and $3 \mu \mathrm{g} / \mathrm{dl}(83 \mathrm{nmol} / \mathrm{l})$ at midnight. Investigation of her adrenal function was carried out with the patient on prednisolone $1 \mathrm{mg}$ tds and fludrocortisone $0.1 \mathrm{mg}$ tds. Five hours after 100 units of intramuscular ACTH on each of 3 consecutive days her plasma cortisol was 4,4 , and $5 \mu \mathrm{g} / \mathrm{dl}(110,110$, and 138 $\mathrm{nmol} / \mathrm{l})$. These results confirmed primary adrenal failure. Auto-antibody testing showed weak positive adrenal, gastric parietal cell, and thyroid colloid and cytoplasmic antibodies. The antinuclear factor test and latex test were negative. She was discharged on cortisol $5 \mathrm{mg}$ qds and fludrocortisone $0.1 \mathrm{mg}$ daily; cortisol was reduced to $5 \mathrm{mg}$ bd and fludrocortisone increased to $0 \cdot 1 \mathrm{mg}$ bd over the next few months.

Fourteen months after the diagnosis of Addison's disease she began to develop pain in the left hip, which spread to involve the right hip, then both knees, both ankles, and the left shoulder. As symptoms progressed she was admitted for assessment on 18 August 1971, 2 years after the initial diagnosis. Examination revealed limited movements of both hips and a Trendelenburg gait. Other joints were normal. ESR, serum uric acid, thyroid function tests, and a $50 \mathrm{~g}$ oral glucose tolerance test were normal.

No diagnosis of her joint pains was made, and her cortisol was in fact increased to $20 \mathrm{mg}$ daily as a single morning dose in the belief that her stiffness might have been due to too low a dose. Fludrocortisone remained at $0.2 \mathrm{mg}$ daily. Despite treatment with phenylbutazone $100 \mathrm{mg}$ tds her symptoms worsened and soon involved the right shoulder as well. In March $1972 x$-rays showed collapse and flattening of both femoral heads with areas of both lucency and sclerosis subchondrally, and a diagnosis of ANB was made. A right Charnley total hip replacement was performed in March 1973 (Fig. 1 shows appearance

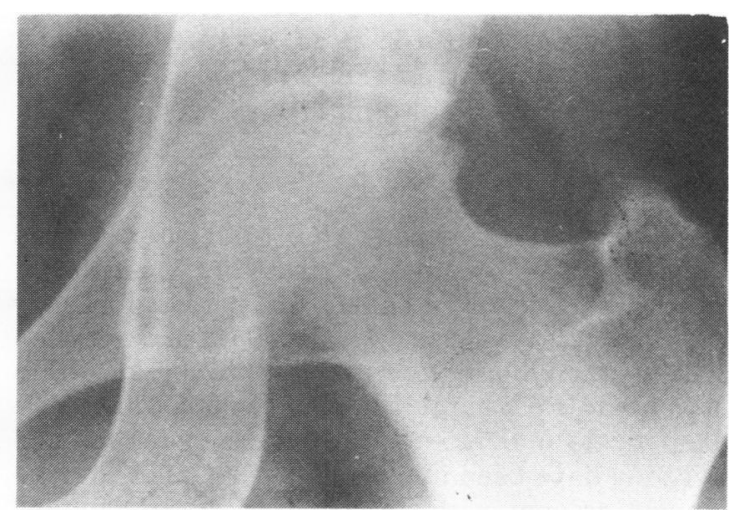

Fig. $1 X$-rays of hips of case 2 (A right, B left) in 1973, showing flattening of both femoral heads, with subchondral sclerosis on the right. 

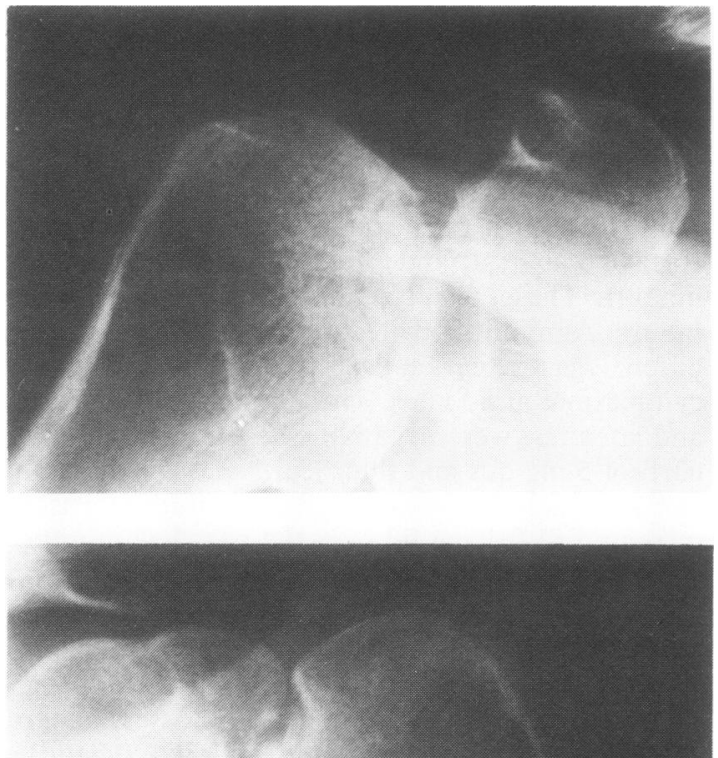

Fig. $2 X$-rays of shoulders (A right, $B$ left) of case 2 in 1977, showing avascular necrosis in both humeral heads.

of hips at that time) followed by a left in October 1973. Subsequently her remaining joint symptoms were controlled on nonsteroidal anti-inflammatory drugs. $X$-rays of both shoulders progressed from normal in September 1971 to advanced avascular necrosis in March 1977 (Fig. 2).

\section{Discussion}

An association between ANB and corticosteroid treatment was first observed in $1957 .{ }^{1}$ Since then it has been described in patients on steroids for many different diseases, most of which, with the exception of systemic lupus erythematosus, are not known to give rise to ANB per se. ${ }^{2}$ Steroids can also cause ANB in patients undergoing renal transplantation ${ }^{3}$ and recently have been implicated in patients with lymphoma treated with combination chemotherapy. ${ }^{4}$ The occurrence of ANB in Cushing's disease further highlights their role. ${ }^{5}$
Although there is much individual variation in susceptibility, the development of ANB seems to correlate with large doses of steroid. ${ }^{6-9}$ Even so, ANB may develop on doses as low as $10 \mathrm{mg}$ prednisolone/day. ${ }^{10}$

However, ANB is not generally reckoned to be a complication of steroid therapy when given in physiological doses as replacement therapy for hypoadrenalism or hypopituitarism-by convention $25-37.5 \mathrm{mg}$ of cortisol, or its equivalent $5-7.5 \mathrm{mg}$ of prednisolone daily.

We have found 3 such cases in a survey of the literature to date, ${ }^{11-13}$ all with pituitary insufficiency, and a further 2 cases are known to the authors, both of hypophysectomy (B. M. Ansell, personal communication). Case 1 reported here was a diabetic, and there is evidence from one study ${ }^{14}$ of an association between diabetes and avascular necrosis of the femoral head. Case 2 is the first report of ANB as a complication of Addison's disease.

Neither case had evidence of hyperuricaemia, hyperlipidaemia, or alcoholism, all of which may be associated with ANB,${ }^{14}$ although case 1 did have a mildly raised cholesterol at $270 \mathrm{mg} / \mathrm{dl}(6.99 \mathrm{mmol} / \mathrm{l})$ in one out of 4 estimations of fasting lipids.

Both cases received doses of steroids which were appropriate as replacement therapy, showed no clinical signs of overdosage, and had no osteoporosis radiologically. Despite this, case 1 developed symptoms of ANB 18 months after the start of treatment, after approximately $2.7 \mathrm{~g}$ of prednisolone, and case 2 had symptoms 14 months after the start of treatment, after a total of approximately $8 \mathrm{~g}$ of cortisol.

The precise mechanism of induction of ANB by corticosteroids is unknown, though there is evidence that steroids may cause hyperlipidaemia and subsequent fat embolisation of the subchondral arterioles. ${ }^{15}$ These 2 cases lend support to the idea that it is the fluctuation in levels of serum cortisol, or its synthetic equivalent prednisolone, that cause ANB rather than the total amount. With a plasma half-life of $80-90$ minutes ${ }^{16}$ cortisol when given orally even in twice daily dosage cannot mimic accurately the normal continuous endogenous secretion by the adrenal cortex.

In case 2 the dose of cortisol was actually temporarily increased before diagnosis in an attempt to alleviate joint stiffness. In fact transient improvement of symptoms in ANB by increasing steroid dose is recognised and may further delay diagnosis. ${ }^{12}$ Every effort should be made to avoid overdosage of the patient on replacement therapy by careful clinical monitoring and estimations of plasma cortisol.

We thank Dr David Boyd and Dr Eva Kohner for permission to report case 1 and Dr John Nabarro for permission to report case 2. 


\section{References}

1 Pietrogrande V, Mastromarino R. Osteopatia da prolongato trammento cortisonico. Ortop traumatol 1957; 25: 791.

2 Ibels L S, Alfrey A C, Huffer W E, Weil R. Aseptic necrosis of bone following renal transplantation. Medicine (Baltimore) 1978; 57: 25-45.

3 Starzl T E, Marchioro T L, Porter K A, et al. Renal homotransplantation: late function and complications. Ann Intern Med 1964; 61: 470-97.

4 Osteonecrosis caused by combination chemotherapy: editorial. Lancet 1982; i: 433.

5 Madell S H, Freeman L M. Avascular necrosis of bone in Cushing's syndrome. Radiology 1964; 83: 1068-70.

6 Abeles M, Urman J D, Rothfield N F. Aseptic necrosis of bone in systemic lupus erythematosus: relationship to corticosteroid therapy Arch Intern Med 1978; 138: 750-4.

7 Harrington K D, Murray W R, Kountz S L, et al. Avascular necrosis of bone after renal transplantation. J Bone Joint Surg 1971; 53A: 203-15.

8 Peiredes A M, Simpson W, Stainsby D, et al. Avascular necrosis of bone following renal transplantation. $Q J$ Med 1975; 44: 459-80.

9 Hawking K M. Avascular necrosis of bone after renal transplantation. N Engl J Med 1976; 294: 397.

10 Solomon L. Drug-induced arthropathy and necrosis of the femoral head. J Bone Joint Surg 1973; 55B: 246-61.

11 Fisher D E, Bickel W H. Corticosteroid-induced avascular necrosis. A clinical study of seventy-seven patients. J Bone Joint Surg 1971; 53A: 859-73.

12 Cruess R L. Experience with steroid-induced avascular necrosis of the shoulder and etiologic considerations regarding osteonecrosis of the hip. Clin Orthop 1978; 130: 86-93.

13 Burrows F G. Avascular necrosis of bone complicating steroid therapy. Br J Radiol 1965; 38: 309-12.

14 Zinn W M, ed.Idiopathic Ischemic Necrosis of the Femoral Head in Adults. Stuttgart: Thieme, 1971.

15 Fisher D E. The role of fat embolism in the etiology of corticosteriod-induced avascular necrosis: clinical and experimental results. Clin Orthop 1978; 130: 68-80.

16 Garber E K, Peng Thim Fan, Bluestone R. Realistic guidelines of corticosteroid therapy in rheumatic diseases. Sem Arthritis Rheum 1981; 11: 231-56.

\section{Book review}

A Back Pain Bibliography. Ed. B. Wyke. Pp. 463. £17.50. Lloyd-Luke (Medical Books): London. 1983.

The literature on most conditions can usually be found in a few specific journals dedicated to a particular field of medicine, but information on back pain can come from almost any discipline, which makes it very difficult to screen for relevant articles. This book is entirely dedicated to listing over 6000 references to back pain, sorted under 13 headings ranging through basic sciences and clinical medicine. The references come from the collections of 5 major research centres, each ensuring a different scope of interest. The present volume covers up to and includes
1979, and the majority are English language publications Though some early references are given, a whole section dedicated to historical references would be fascinating.

It is intended that supplements should update the work every 3 years. I feel that the next one along with a historical section could with benefit include a list of university degree dissertations on back pain topics, as the detail in such work is often of great help in the preliminary stages of designing research projects.

Even with the available information retrieval from computerised sources this bibliography is a most relevant and essential handbook for all those who study and practise in the field of back pain. 